Published in International Journal of Quality \& Reliability Management, 2018, vol. 35, no. 4, pp. 846-856 which should be cited to refer to this work

DOI: https://doi.org/10.1108/IJQRM-01-2017-0007

\title{
Are customers ready to accept revenue management practices in the restaurant industry?
}

Reza Etemad-Sajadi

\begin{abstract}
Purpose - The purpose of this research is to investigate the application of revenue management practices to the restaurant industry. We want to observe customers' readiness to accept revenue management practices based on price variation, booking policy, table management, and control duration. We also want to measure the impact of these four practices on customer patronage intention.

Design/methodology/approach - A survey was conducted with 251 respondents. As we had several latent variables, we used partial least squares (PLS), a variance-based structural equation modeling method.

Findings - We found that the majority of these practices are perceived unfair. The only two practices that are considered as fair are price variation between lunch/dinner, and cancellation in case of late. The most unfairly felt practice is the policy related time spent at the table. Results also showed that the perceived fairness of these practices influences customer patronage intention. We observed that price variation according to the lunch/dinner period, Weekday/Weekend period, and time of the day will influence the desire to frequent the restaurant. Booking policy will also impact customer patronage intention. Table management and control duration policies do not impact customer patronage intention, even if these practices are perceived unfair.

Practical implications - Restaurant managers, desiring to apply revenue management practices, should be aware of the fact that practices linked to price variation will have a stronger influence on the customer intention to revisit the company than control duration practices. Moreover, restaurant managers must "educate" their clients by clearly communicating the advantages of these practices for the customers.

Originality/value - Even if several studies focused on the fairness perceived of revenue management practices in hospitality industry, there is a lack of research about the impact of price variation and control duration on patronage intention, especially for the restaurant industry. This is the first time we measured the concrete impact of price variation, booking policy, table management, and control duration on patronage intention. Moreover, we integrated several new practices that have never been studied in the past such as the date of booking (e.g. 5\% reduction if the booking was done 4 days in advance) or the fact of changing tables for dessert and coffee.
\end{abstract}

Keywords Revenue management, Restaurant industry, Variable pricing, Control duration, Booking policy, Table management

Paper type Research paper 


\section{Are customers ready to accept revenue management practices in the restaurant industry?}

\section{INTRODUCTION}

Revenue management can be defined as the application of information systems and pricing strategies to allocate the right capacity to the right customer at the right place at the right time (Kimes and Wirtz, 2003; Weatherford and Bodily, 1992). These practices are well known for airlines/hotels and seem to be well accepted by the clients in these two industries as they seem to understand the process and to see the benefit for them. Recently several research (i.e. Guerriero et al., 2014; Bell and Pliner, 2013; Thompson, 2015) focused their effort on observing the impact of these practices in the restaurant industry. The idea of this research is to see how customers can perceive the fairness of these practices in the restaurant industry. Of course, several dimensions such as waiting time, staff attitude, food quality, food variety, etc. affect customer repurchase frequency (Law et al.; 2004). Nevertheless, restaurant managers can also increase patronage intention by using revenue management techniques. However, these practices are underused due to difficulties to control duration. In the same time, people can have the perception that the variation of prices based on demand is unfair. It is not usual in the restaurant industry and customers do not seem to find advantages of these practices. An unfair perception will influence the customers' behaviour with the risk of decreasing the frequentation of the establishment (Kahneman et al., 1986). Revenue management strategies will only be successful if customers perceive them to be fair (Kimes and Wirtz, 2003; Bei and Chiao, 2001). Based on the manner revenue management practices will be perceived by the different profile of clients, we want to know more about their behaviour in the future. Knowing what customers are ready to accept becomes a crucial question. Therefore, the aim of this paper is to evaluate customers' perception of revenue management practices in the restaurant industry and to compare the impact of practices such as variable pricing and control duration on patronage intention. This research is important as 
it will contribute to better understand the practices that are judged to be fair in the mind of clients and in the same time, restaurant managers will increase their income by using the most acceptable techniques. Even if several studies focused on the fairness perceived of revenue management practices in hospitality industry (e.g., Kimes and Wirtz, 2002; Wirtz and Kimes, 2007; Kimes et al., 1998; Choi and Mattila, 2004; Denizci Guillet and Mohammed, 2015; Beldona and Namasivayam, 2006; Erdem and Jiang, 2016, El Haddad, 2015), there is a lack of research about the impact of price variation and control duration on patronage intention, especially for the restaurant industry. This is the first time we measured the concrete impact of price variation, booking policy, table management, and control duration on patronage intention. Moreover, we integrated several new practices that have never been studied in the past such as the date of booking (e.g. $5 \%$ reduction if the booking was done 4 days in advance) or the fact of changing tables for dessert and coffee.

\section{LITERATURE REVIEW AND HYPOTHESES DEVELOPMENT}

\section{Industries applying revenue management practices}

Revenue management or yield management as it was first called in the airline industry is the application of analytical tools to predict consumer behaviour and optimize product availability and price in order to maximize revenue growth (Cross, 1997). The challenge is to understand customers' perception of product value and accurately align product prices, placement and availability with each customer segment (Cross, 1997). For Kimes (2004), a good revenue management strategy consists of the use of two levers i) duration control and ii) demand based pricing. As mentioned above, the airline industry was the first to develop these practices in the early 70s by implementing highly discounted fare products to fill seats that would otherwise remain empty (Cross et al., 2009). To control the risk of revenue dilution (high fare passengers' shift to the newly discounted fare) restrictions were put in place (Cross et al., 2009). Hotel and rental car are two other major traditional industries where revenue 
management has been applied (Chiang et al., 2007). Because of its success in airline and hotel industries, researchers and practitioners have attempted to adopt it in a wide range of industries such as restaurants, theaters, casinos, etc. (Choi et al., 2015; Chiang et al., 2007). The common points with these different industries are fixed capacity, perishable inventory, demand inventory, time variable demand, appropriate cost structure, and customer segmentation (Kimes, 2004). In fact a lot of service providers can take advantage of revenue management. These practices can result in a strong increase in revenue for the hospitality industry (Sanket and Bowman, 2004).

\section{Fairness of revenue management practices}

Fairness perception is the judgment of whether or not customers accept an outcome and/or a transaction process (Bolton et al., 2003). As pricing policy is a key element of revenue management, the degree of fairness perceived by customers plays an important role in their satisfaction (Bei and Chiao, 2001) and their positive or negative word of mouth (Bougie et al., 2003). Previous research about perceived fairness has examined the effects of rate fences when they are associated with i) a surcharge or a discount in price, ii) the information given (or not) to the customer about pricing policy, and iii) the knowledge (or not) about a reference price. Table 1 adapted from Heo and Lee (2011) summarized the most important research done on fairness perceptions of revenue management in the hospitality industry.

\section{Table 1}

Summary of research on fairness perceptions of RM in the hospitality industry

\begin{tabular}{l|l|l|l|} 
Author(s) & \multicolumn{2}{c}{ Title } & $\begin{array}{l}\text { Perceived fairness of } \\
\text { yield management }\end{array}$ \\
Kimes (1994) & $\begin{array}{l}\text { Airline and } \\
\text { hotel } \\
\text { yerceived fairness of } \\
\text { yield management } \\
\text { familiarity with discount, cancellation } \\
\text { penalties }\end{array}$ \\
\hline Kimes (2002) & $\begin{array}{l}\text { Airline and } \\
\text { hotel }\end{array}$ & $\begin{array}{l}\text { Day of booking, discount asked, } \\
\text { familiarity with discount, cancellation } \\
\text { penalties }\end{array}$ \\
\hline
\end{tabular}




\begin{tabular}{|c|c|c|c|}
\hline Kimes and Wirtz (2002) & $\begin{array}{l}\text { Perceived fairness of } \\
\text { demand-based } \\
\text { pricing for } \\
\text { restaurants }\end{array}$ & Restaurant & $\begin{array}{l}\text { Lunch/dinner, weekday/weekend, time } \\
\text { of the day, table location, two-for-one } \\
\text { coupons }\end{array}$ \\
\hline Kimes and Wirtz, (2003a, b) & $\begin{array}{l}\text { Has revenue } \\
\text { management become } \\
\text { acceptable? }\end{array}$ & Restaurant & $\begin{array}{l}\text { Lunch/dinner, weekday/weekend, time } \\
\text { of day, table location, two-for-one } \\
\text { coupons }\end{array}$ \\
\hline Choi and Mattila (2004) & $\begin{array}{l}\text { Hotel revenue } \\
\text { management and its } \\
\text { impact on customers' } \\
\text { perceptions of } \\
\text { fairness }\end{array}$ & Hotel & $\begin{array}{l}\text { Day of the week, weekday/weekend, } \\
\text { length of stay, day of booking }\end{array}$ \\
\hline Choi and Mattila (2005) & $\begin{array}{l}\text { Impact of } \\
\text { Information on } \\
\text { Customer Fairness } \\
\text { Perceptions of Hotel } \\
\text { Revenue } \\
\text { Management }\end{array}$ & Hotel & $\begin{array}{l}\text { Day of the week, length of stay, day of } \\
\text { booking }\end{array}$ \\
\hline Choi and Mattila (2006) & $\begin{array}{l}\text { The role of disclosure } \\
\text { in variable hotel } \\
\text { pricing: a cross- } \\
\text { cultural comparison } \\
\text { of customers' } \\
\text { fairness perceptions }\end{array}$ & Hotel & $\begin{array}{l}\text { Day of the week, length of stay, day of } \\
\text { booking }\end{array}$ \\
\hline $\begin{array}{l}\text { Beldona and Namasivayam } \\
\text { (2006) }\end{array}$ & $\begin{array}{l}\text { Gender and demand- } \\
\text { based pricing: } \\
\text { differences in } \\
\text { perceived } \\
\text { (un)fairness and re- } \\
\text { patronage intentions }\end{array}$ & Hotel & $\begin{array}{l}\text { Seasonality, day of booking, } \\
\text { weekday/weekend }\end{array}$ \\
\hline Wirtz and Kimes (2007) & $\begin{array}{l}\text { The moderating role } \\
\text { of familiarity of } \\
\text { fairness perceptions } \\
\text { of revenue } \\
\text { management pricing }\end{array}$ & Restaurant & Lunch/dinner, duration \\
\hline Beldona and Kwansa (2008) & $\begin{array}{l}\text { The impact of } \\
\text { cultural orientation } \\
\text { on perceived fairness } \\
\text { over demand-based } \\
\text { pricing }\end{array}$ & Hotel & $\begin{array}{l}\text { Seasonality, booking date, } \\
\text { weekday/weekend }\end{array}$ \\
\hline
\end{tabular}

Source: Heo and Lee (2011), readapted.

Kimes (1994) studied the perceived fairness of several pricing policies in the airline and hotel industries. The pricing policy was based on the i) day of booking, ii) requested discount (customers who did not insist on a lower rate received no discount, customers who insisted on a lower rate received $10-20 \%$ discount), iii) familiarity with discount (no discount if customer did not ask), and iv) cancellation penalties. She found that revenue management practices are less acceptable in the hotel industry compared to the airline industry. Kimes repeated this study in 2002 and found that there was no difference in fairness perception 
between the two industries. Customers seemed to accept these practices more and more in the hotel industry. Kimes and Wirtz (2003b) tried to test customer reaction to various rate fences in the restaurant industry. The pricing policy was based on i) lunch/dinner period, ii) weekday/weekend period, iii) time of the day, iv) table location, and v) two-for-one coupons. They found that revenue management pricing in the form of coupons, time of day pricing and lunch/dinner pricing are considered to be fairer compared to the other practices. Choi and Mattila (2005) found that consumers who receive no information about pricing policy as i) day of the week, ii) weekday/weekend, iii) length of stay, and iv) day of booking, judged that the process was unfair. Therefore, it seems important and fair to communicate the pricing policy to clients as they expect to be informed. Wirtz and Kimes (2007) found that framing and fencing conditions (e.g. whether a respondent was at an advantage or disadvantaged by revenue management practices) have strong effects on fairness perceptions when customers are less familiar with revenue management pricing. This involves taking time to explain its advantages to customers. Building on the findings of prior empirical studies (e.g., Han and Ryu, 2009; Martín-Consuegra et al., 2007; Varki and Colgate, 2001) we judge that customers' perception of fairness related to revenue management practices (i.e. variation of prices and control duration) can potentially impact the patronage intention which is the customers' likelihood of revisiting the company in the future (Hellier et al., 2003). Therefore, we propose the following hypotheses:

Hypothesis 1: The perceived fairness of practices related to variation of prices (according to the day/hour) will have a positive impact on patronage intention.

Hypothesis 2: The perceived fairness of practices related to booking policy will have a positive impact on patronage intention.

Hypothesis 3: The perceived fairness of practices related to table management policy will have a positive impact on patronage intention.

Hypothesis 4: The perceived fairness of practices related to control duration will have a positive impact on patronage intention. 


\section{Sampling, data collection procedures, and measures}

An on-line survey was conducted. We sent the link via email to students enrolled in a bachelor of science in international hospitality management program at a private university in Switzerland (43.6\% of our sample). In order to have a better age distribution, we also sent the on-line survey to a convenient sample (56.4\% of our sample). We did an ANOVA test for identifying the homogeneity of our sample. This test confirmed the fact that we have no significant differences between our two profiles. We received 251 answers, of which 10 questionnaires were incomplete. Thus, the final sample consisted of 241 respondents. The gender of these 241 respondents was divided with 116 male and 125 female. The average age of these 241 respondents was 28 . The questionnaire was composed of three parts. First, we described the scenario (going with friends/family to a mid-scale restaurant - prices between $15 €$ and $25 €$ - with table service). Second, we started with questions related to customers’ perception of restaurant revenue management practices. The respondents were asked to give their perception on a 5-point scale from 1 (totally unfair) to 5 (totally fair), where a score of 3 represented no opinion (neutral). The third part of the questionnaire concerned personal data on the respondent's profile.

For measuring revenue management practices applied to the restaurant industry, we adapted items from Kimes and Wirtz (2002) and added some other practices that will be mentioned below. First, we wanted to see how customers view various pricing differences based on various factors such as lunch/dinner period, weekday/weekend period, and time of day. The second variable is booking policy. For that, we measured the perceived fairness of the date of booking (e.g. reduction if the booking was done in advance), the fact that a credit card number was required to confirm booking, credit card debit if no-show, pay extra in case of late arrival, and cancellation in case of late arrival. Third, as far as table management is concerned, we measured the perceived fairness of practices related to the number of people at the table, the location of the table (e.g. price variation based on table view, space, etc.), and 
the fact that it was sometimes necessary to change tables for dessert/coffee. Fourth, for measuring control duration policy, we focused on the speed of service, the time spent at the table (e.g. the price will depend on the time spent at the table), the fact to leave the table for a second service, and a limited time for each table (e.g. in advance, the customer knows how much time the table is allocated to him/her). As far as the patronage intention is concerned, we selected 3 items adapted from Hellier et al. (2003) in order to better understand clients' desire to frequent or not the restaurant in the future (see note section of Table 3).

\section{Reliability and validity of measures}

Table 2 shows that all latent variables have a composite reliability higher than 0.7 , confirming that the scale reliabilities have adequate and stable measurement properties. Validity is assessed based on three main criteria, namely unidimensionality, convergent, and discriminant validity. An exploratory factor analysis can verify unidimensionality. For each construct, only the first eigenvalue is over one and thus, unidimensionality is confirmed and validated (Dröge, 1996). Convergent and discriminant validity are components of a larger measurement concept known as construct validity (Straub et al., 2004). Convergent validity is shown when each measurement item is strongly correlated with its construct. It is usually satisfied by retaining variables with loadings greater than 0.5 , indicating that they share sufficient variance with their related construct (see Table 3).

Table 2

Reliability and discriminant validity

\begin{tabular}{lcccccc}
\hline Constructs & $\begin{array}{c}\text { Composite } \\
\text { reliability }\end{array}$ & $\mathbf{1}$ & $\mathbf{2}$ & $\mathbf{3}$ & $\mathbf{4}$ & $\mathbf{5}$ \\
\hline $\begin{array}{l}\text { 1. Variation pricing policy (according } \\
\text { to the day/hour) }\end{array}$ & .82 & $.77^{\mathrm{a}}$ & & & \\
\hline 2. Booking policy & .72 & $0.24^{* *}$ & .61 & & \\
\hline 3. Table management policy & .70 & $0.26^{* *}$ & $0.49^{* *}$ & .74 & \\
\hline 4. Control duration policy & .76 & $0.21^{* *}$ & $0.47^{* *}$ & $0.52^{* *}$ & .66 \\
\hline 5. Patronage intention & .80 & $0.50^{* *}$ & $0.40^{* *}$ & $0.27^{* *}$ & $0.28^{* *}$ & .76 \\
\hline
\end{tabular}


** $\quad$ Correlation is significant at the 0.01 level.

a Diagonal: (Average Variance Extracted $)^{1 / 2}=\left(\Sigma \lambda_{\mathrm{i}}^{2} / \mathrm{n}\right)^{1 / 2}$

In our case, we deleted the item called 'cancellation in case of late arrival' as the loading was insufficient. Discriminant validity is satisfied when each measurement item is weakly correlated with all other constructs, except with the one to which it is theoretically associated (Gefen and Straub, 2005). Table 2 shows the intercorrelation of the research constructs. The diagonal of this matrix represents the square root of the average variance extracted. For adequate discriminant validity, the diagonal elements should be significantly larger than the correlation of the specific construct with any of the other constructs and should be at least 0.5 (Fornell and Larcker, 1981). One can claim that discriminant validity is confirmed and sufficient to support the model.

\section{Data analysis method}

Structural equation modeling (SEM) was adopted to test the hypotheses because the model contains latent variables. We chose partial least square (PLS), because it does not require a large sample (Fornell and Lacker, 1981). SmartPLS 2.0 was used for the analysis. We employed a bootstrapping method (200 sub-samples) to test the significant level of regression path coefficients.

\section{RESULTS}

\section{Descriptive analysis}

Table 3 shows the descriptive statistics for all of our items and the items loadings. In general, almost all of these practices were rejected in our research. The two practices that seem to be acceptable by customers are price variation between lunch and dinner (mean = 3.09) and cancellation in case of late arrival (mean $=3.37$ ). The third fairest practice is the price variation based on the date of booking (mean $=2.71$ ). However, this value is lower than 
3 and thus seems to also be judged as slightly unacceptable. The most unfairly felt practice is price variation based on time spent at the table (mean $=1.54)$. Customers seem to completely reject this practice and the majority of the other practices.

Table 3

Descriptive statistics and items' loadings

\begin{tabular}{|c|c|c|c|c|c|}
\hline Constructs & $\begin{array}{c}\text { Item } \\
\text { loading }\end{array}$ & Mean & $\begin{array}{c}\text { Std } \\
\text { deviation }\end{array}$ & Min & Max \\
\hline \multicolumn{6}{|l|}{ 1. Variation pricing policy (according to the day/hour) } \\
\hline $1.1 \mathrm{Lunch} /$ dinner period & .732 & 3.09 & 1.27 & 1 & 5 \\
\hline 1.2 Weekday/Weekend period & .793 & 2.57 & 1.21 & 1 & 5 \\
\hline 1.3 Time of the day & .808 & 2.47 & 1.22 & 1 & 5 \\
\hline \multicolumn{6}{|l|}{ 2. Booking policy } \\
\hline 2.1 Cancellation in case of late arrival (more than $20 \mathrm{~min}$ ) & .259 & 3.37 & 1.28 & 1 & 5 \\
\hline 2.2 Date of booking & .733 & 2.71 & 1.39 & 1 & 5 \\
\hline 2.3 Pay extra in case of late arrival & .632 & 2.05 & 1.00 & 1 & 5 \\
\hline 2.4 To give bank data for booking & .569 & 2.00 & 1.11 & 1 & 5 \\
\hline 2.5 Debit if no-show & .523 & 1.84 & 1.05 & 1 & 5 \\
\hline \multicolumn{6}{|l|}{ 3. Table management policy } \\
\hline 3.1 Number of people at the table & .709 & 2.56 & 1.38 & 1 & 5 \\
\hline 3.2 Location of the table & .705 & 1.97 & 1.06 & 1 & 5 \\
\hline 3.3 To change table for dessert/coffee & .537 & 1.71 & 1.01 & 1 & 5 \\
\hline \multicolumn{6}{|l|}{ 4. Control duration policy } \\
\hline 4.1 To leave the table for a second service & .585 & 2.49 & 1.32 & 1 & 5 \\
\hline 4.2 Speed of service & .514 & 2.11 & 1.13 & 1 & 5 \\
\hline 4.3 A limited time for each table & .657 & 2.15 & 1.27 & 1 & 5 \\
\hline \multirow[t]{3}{*}{ 4.4 Time spent at the table } & .768 & 1.54 & .87 & 1 & 5 \\
\hline & .703 & & & & \\
\hline & .790 & 2.54 & .93 & 1 & 5 \\
\hline 5. Patronage intention ${ }^{a}$ & .789 & & & & \\
\hline
\end{tabular}

Notes:

a $\quad 3$ items define patronage intention: 'I will continue to frequent this type of restaurant if the overall experience is good', 'Overall I accept a restaurant applying these practices', and 'I will not frequent this type of restaurant in the future'(N).

\section{Results}

Figure 1 presents the results of the PLS analysis and the values of different path coefficients. The Stone-Geisser $\mathrm{Q}^{2}$ of patronage intention is equal to $0.197 . \mathrm{Q}^{2}$ measures how well observed values are reconstructed by the model and its parameter estimates (Chin, 1998). The technique represents a synthesis of function fitting and cross-validation (Henseler et al., 2009). If it is negative, the model has no predictive relevance; values around 0.15 indicate a medium predictive relevance and around 0.35 a large predictive relevance 
(Henseler et al., 2009). In this model, the independent variables indicate a medium predictive relevance of the patronage intention latent variable.

One can observe that the perceived fairness based on variable pricing, booking, table management, and control duration account for $34.7 \%$ of the patronage intention. Variable pricing practices highly influence the patronage intention. A path coefficient significant at 0.01 level $(\gamma=0.431)$ confirms that these practices influence the desire of clients to frequent or not the relevant restaurant in the future. Therefore, $H 1$ is supported. The perception about the booking policy also impacts the patronage intention $(\gamma=0.278)$. In other words, the booking policy of a restaurant can clearly influence customers' desire to return to that restaurant. $\mathrm{H} 2$ is also supported. As far as $\mathrm{H} 3$ and $H 4$ are concerned, they are not supported in our research. Indeed, even if table management and control duration are perceived in an unfavorable, relative to the other variables, they have no significant impact on patronage intention.

\section{Figure 1}

\section{Results of the PLS analysis}

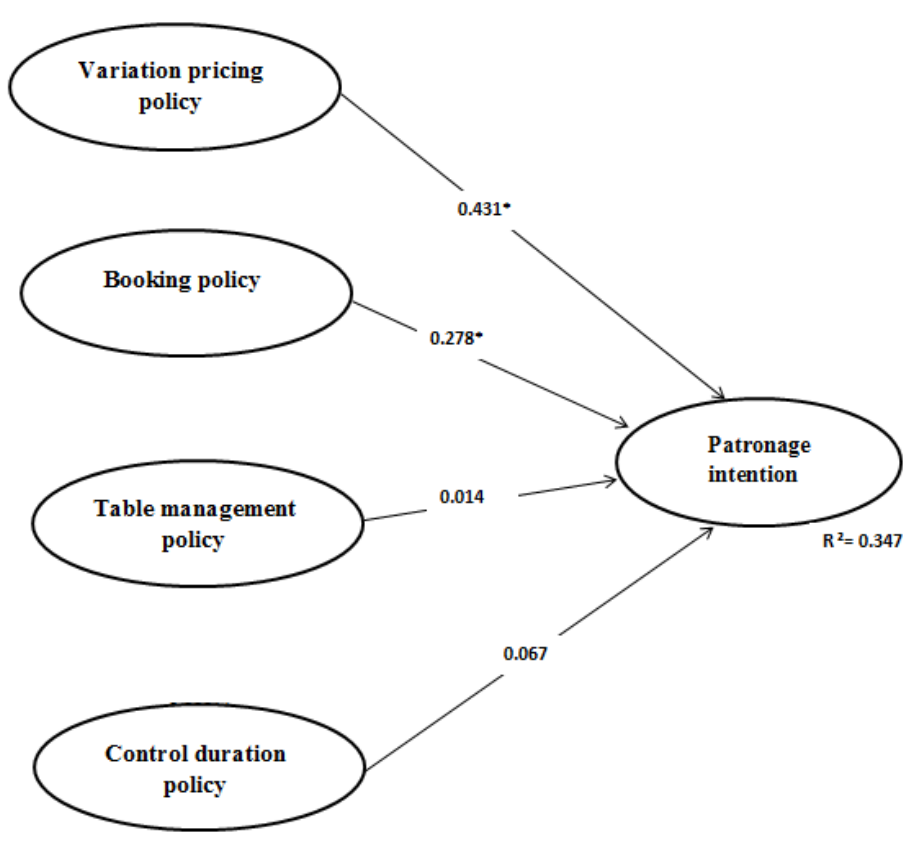

Notes:

* Significant at 0.01 level. 


\section{Discussion}

Revenue management practices are well known for the airline and hotel industries and customers seem to accept price variation in these two industries. But customers do not see any benefit for them in the restaurant industry. As it took time for these practices to be more acceptable in the hotel industry (Kimes, 2016), it might take more time to render these practices acceptable in the restaurant industry. It seems that customers are not yet ready for that. This was confirmed in the research done by Kimes (1994) who found a significant difference of perception of these practices between the airline and the hotel industries. However, in 2002, Kimes found that revenue management practices in the two industries have the same level of acceptability. As far as the restaurant industry is concerned, Wirtz and Kimes (2007) argued that as customers become more and more familiar with these practices, the unfairness perception can decline over time. Moreover, in this research we identified that the control duration policy (average of 1.84) is judged more unfair than the variable pricing policy (average of 2.30), booking policy (average of 2.08), and table management policy (average of 1.86). In parallel, we noticed that the variable pricing lever has a stronger influence on patronage intention than booking, table management, and control duration policies. It means that practices linked to price variation will influence customer behaviour, even if these practices are judged fairer than booking, table management, and control duration policies.

\section{Managerial implications}

Restaurant managers, who wish to apply some revenue management practices, should be aware of the above findings and "educate" consequently their clients. It seems important to ensure that customers see the advantages of these practices for themselves and this must be the priority for the company before applying these practices. Clients should be aware and recognize the positive side of these practices and this is the responsibility of firms through a 
good strategy of communication. The company should focus on the interactive communication between its employees and customers. Indeed, when we talk about service companies, in-front employees should be considered as our best channel of communication. They can teach to clients the advantages of these practices. For example, price variation based on the date of booking, is a practice that can be very useful for clients. Nevertheless, it is the responsibility of the restaurant to be sure that this kind of practice is well understood by its clients in order to create a positive word-of-mouth around that. Another important issue is the profile of our clients. Indeed, we discovered that young people accept better practices related to booking policy and table management than old people. The reasons come from the fact that they are more aware about these practices and try to reduce their budgets. Thus, they see the financial advantage for themselves of these practices. Therefore, restaurants desiring to apply revenue management practices should also integrate the characteristics and profile of their clients. As far as the gender is concerned, we found no significant difference. Therefore, we cannot confirm previous research showing that women find revenue management practices less fair than men. In order to conclude, one can claim that the application of these practices can only work if they create value for your customers, even before creating value for your restaurant.

\section{Limitations and future work}

This study is subject to limitations. First, we must be careful in the generalization of our findings to all restaurants. This study focused on mid-range restaurants where the average main course per person is between $15 €$ and $25 €$ (table service). A possible area for future research is to explore other types of restaurants and then compare the findings with our results.

Second, this research was done in Switzerland and based on two samples (European students enrolled in a bachelor of science in international hospitality management program at 
a private university in Switzerland and a convenient sample). Nevertheless, we found no statistically significant difference between the two samples.

Third, in this research we asked customers about their perceived fairness of restaurant revenue management practices and their return intention. We are note measuring how frequently the customers visit these kind of restaurants. We are just evaluating the customer intention of visiting these restaurants in the future. Therefore, we can have a bias.

In the future, it may be useful to do the same research in 5-10 years and observe the evolution of behaviors and perceptions over time. For example, Kimes (1994) studied the perceived fairness of several pricing policies in the airline and hotel industries. She found that revenue management practices are less acceptable in the hotel industry compared to the airline industry. Kimes repeated this study in 2002 and found that there was no difference in fairness perception between the two industries. Customers seemed to be increasingly accepting of these practices in the hotel industry. In the future, it could be interesting to observe changes in European customers' perception of these practices as they apply to the restaurant industry. 


\section{REFERENCES}

Bei, L.T. and Chiao, Y. (2001). "The determinants of customer loyalty: an analysis of intangible factors in three service industries”, International Journal of Commerce and Management, Vol. 16 No. 3/4, pp. 162-177.

Beldona, S. and Namasivayam, K. (2006), “Gender and demand-based pricing: differences in perceived (un)fairness and repatronage intentions”, Journal of Hospitality and Leisure Marketing, Vol. 14 No. 4, pp. 89-107.

Bell, R. and Pliner, P.L. (2013), “Time to eat: the relationship between the number of people eating and meal duration in three lunch settings”. Appetite, 41, pp. 215-218.

Bolton, L.E., Warlop, L. and Alba, J.W. (2003), “Consumer perception of price (un)fairness”, Journal of Consumer Research, Vol 29 No. 4, pp. 474-491.

Bougie, R., Pieters, R. and Zeelenberg, M. (2003), “Angry customers don’t come back, they get back: the experience and behavioral implications of anger and dissatisfaction in services”, Journal of the Academy of Marketing Science, Vol. 31 No. 4, pp. 377-393.

Chiang, W.C., Chen, J.C.H. and Xu, X. (2007), “An overview of research on revenue management current issues and future research”, International Journal of Revenue Management, Vol. 1 No. 1, pp. 97-128.

Chin, W. W. (1998), “The Partial least squares approach to structural equation modeling”, In G. A. Marcoulides (Ed.), Modern Methods for Business Research, New Jersey: Lawrence Elbaum Associates.

Choi, C., Jeong, M., \& Mattila, A. S. (2015), "Revenue management in the context of movie theaters: Is it fair?”, Journal of Revenue and Pricing Management, Vol. 14 No. 2, pp. 72-83.

Choi, S. and Mattila, A.S. (2005), “Impact of information on customer fairness perceptions of hotel revenue management”, Cornell Hotel and Restaurant Administration Quarterly, Vol. 46 No. 4, pp. 444-451. 
Choi, S. and Mattila, A.S. (2006), “The role of disclosure in variable hotel pricing”, Cornell Hotel and Restaurant Administration Quarterly, Vol. 47 No. 1, pp. 27-35.

Cross, R., Higbie, J. and Cross, D. (2009), "Revenue management's renaissance: a rebirth of the art and science of profitable revenue”, Cornell Hospitality Quarterly, Vol. 50 No. 1, pp. 56-81.

Cross, R. (1997), “Revenue Management: Hard-Core Tactics for Market Domination”, New York: Broadway Books.

Denizci Guillet, B. \& Mohammed, I. (2015), “Revenue management research in hospitality and tourism: A critical review of current literature and suggestions for future research”, International Journal of Contemporary Hospitality Management, Vol. 27 No. 4, pp. 526-560.

Dröge, C. (1996), “How valid are measurements?”, Research Issues, Eli Broad Graduate School of Management, Michigan State University.

El Haddad, R. (2015), "Exploration of revenue management practices-case of an upscale budget hotel chain”, International Journal of Contemporary Hospitality Management, Vol. 27 No. 8, pp. 1791-1813.

Erdem, M. \& Jiang, L. (2016), “An overview of hotel revenue management research and emerging key patterns in the third millennium”, Journal of Hospitality and Tourism Technology, Vol. 7 No. 3, pp. 300-312.

Fornell, C.R. and Larcker, D. (1981), "Evaluating structural equation models with unobservable variables and measurement error”, Journal of Marketing Research, Vol. 18 No.1, pp. 39-50.

Gefen, D. and Straub, D. (2005), “A practical guide to factorial validity using Pls-graph: tutorial and annotated example”, Communications of the Association for Information Systems, Vol. 16 No.5, pp. 91-109. 
Guerriero, F., Miglionico, G., and Olivito, F. (2014), "Strategic and operational decision in restaurant revenue management”. European Journal of Operational Research, Vol. 237, pp. 1119-1132.

Han, H. and Ryu, K. (2009), “The roles of the physical environment, price perception, and customer satisfaction in determining customer loyalty in the restaurant industry”, Journal of Hospitality \& Tourism Research, Vol. 33, pp. 487-510.

Hellier, P. K., Geursen, G. M., Carr, R. A., and Rickard, J. A. (2003), “Customer repurchase intention: A general structural equation model”, European Journal of Marketing, Vol. 37 No. 11/12, 1762-1800.

Henseler, J., Ringle, C. M. and Sinkovics, R. R. (2009), “The use of partial least square path modeling in international marketing”, New Challenges to International Marketing, in Advances in International Marketing series, Vol. 20, pp. 277-319.

Heo, C. Y. and Lee, S. (2011), "Influences of consumer characteristics on fairness perceptions of revenue management pricing in the hotel industry”, International Journal of Hospitality Management, Vol. 30, pp. 243-251.

Jain, S. and Bowman, B. (2004), "Measuring the gain attributable to revenue management”, Journal of Revenue and Pricing Management, Vol. 4 No. 1, pp. 83-94.

Kahneman, D., Knetsch, J.L. and Thaler, R. (1986), "Fairness as a constraint on profit seeking: entitlements in the market”, The American Economic Review, Vol. 76 No. 4, pp. 728-741.

Kimes, S. E. (2016), “The evolution of hotel revenue management”, Journal of Revenue and Pricing Management, Vol. 15 No. 3-4, pp. 247-251.

Kimes, S.E. (1994), "Perceived fairness of yield management”, Cornell Hotel and Restaurant Administration Quarterly, Vol. 35 No. 1, pp. 22-29. 
Kimes, S. E., Chase, R. B., Choi, S., Lee, P. Y., \& Ngonzi, E. N. (1998), "Restaurant revenue management applying yield management to the restaurant industry”, Cornell Hotel and Restaurant Administration Quarterly, Vol. 39 No. 3, pp. 32-39.

Kimes, S.E. (2002), “Perceived fairness of yield management”, Cornell Hotel and Restaurant Administration Quarterly, Vol. 43 No. 1, pp. 22-30.

Kimes, S.E. (2004), "Restaurant revenue management: implementation at chevys arrowhead”, Cornell Hotel and Restaurant Administration Quarterly, Vol. 43 No. 4, pp. 48-57.

Kimes, S.E. and Wirtz, J. (2002), "Perceived fairness of demand-based pricing for restaurants”, Cornell Hotel and Restaurant Administration Quarterly, Vol. 43 No. 1, pp. 31-37.

Kimes, S.E. and Wirtz, J. (2003a), "Perceived fairness of revenue management in the us golf industry”, Journal of Revenue and Pricing Management, Vol. 1 No. 4, pp. 332-344.

Kimes, S.E. and Wirtz, J. (2003b), "Has revenue management become acceptable? findings from an international study on the perceived fairness of rate fences”, Journal of Service Research, Vol. 6 No. 2, pp. 125-135.

Law, A. K., Hui, Y. V., \& Zhao, X. (2004), "Modeling repurchase frequency and customer satisfaction for fast food outlets”, International Journal of Quality \& Reliability Management, Vol. 21 No. 5, pp. 545-563.

Martín-Consuegra, D., Molina, A., \& Esteban, Á. (2007), “An integrated model of price, satisfaction and loyalty: An empirical analysis in the service sector”, Journal of Product \& Brand Management, Vol. 16 No. 7, pp. 459-468.

Rosa Díaz, I.M. (2004), “Price knowledge: effects of consumers’ attitudes towards prices, demographics, and socio-cultural characteristics”, Journal of Product and Brand Management, Vol. 13 No. 6, pp. 406-428. 
Sanket, J. and Bowman, B. (2004), "Measuring the gain attributable to revenue management”, Journal of Revenue Management and Pricing management, Vol. 4 No. 1, pp. 83-94.

Straub, D., Boudreau, M.C. and Gefen, D. (2004), "Validation guidelines for IS positivist research”, Communications of the Association for Information Systems, Vol. 14, pp. 380-426.

Sweeney, P.D. and McFarlin, D.B. (1997), "Process and outcome: gender differences in the assessment of justice”, Journal of Organizational Behavior, Vol. 18 No. 7, pp. 83-98.

Thompson, G. M. (2015), “Deciding whether to offer "early-bird” or "night-owl” specials in restaurants: A cross-functional view”, Journal of Service Research, Vol. 27, pp. 1-15.

Varki, S. and Colgate, M. (2001), “The role of price perception in an integrated model of behavioral intentions”, Journal of Service Research, Vol. 3 No. 3, pp. 232-240.

Weatherford, L.R. and Bodily, S.E. (1992), “A taxonomy and research overview of perishable-asset revenue management: yield management, overbooking and pricing”, Operations Research, Vol. 40 No. 5, pp. 831-844.

Wirtz, J. and Kimes, S.E. (2007), “The moderating role of familiarity in fairness perceptions of revenue management pricing”, Journal of Service Research, Vol. 9 No. 3, pp. 229240. 